\title{
THE ROLE OF DEFORESTATION IN THE DYNAMICS OF THE ECONOMIC PROFILE OF THE AFFECTED LOCALITIES
}

\author{
DOI: http://dx.doi.org/10.18509/GBP.2020.49 \\ UDC: 332.146.2:630*232-021.351]:303.723(498)"2000/2018”
}

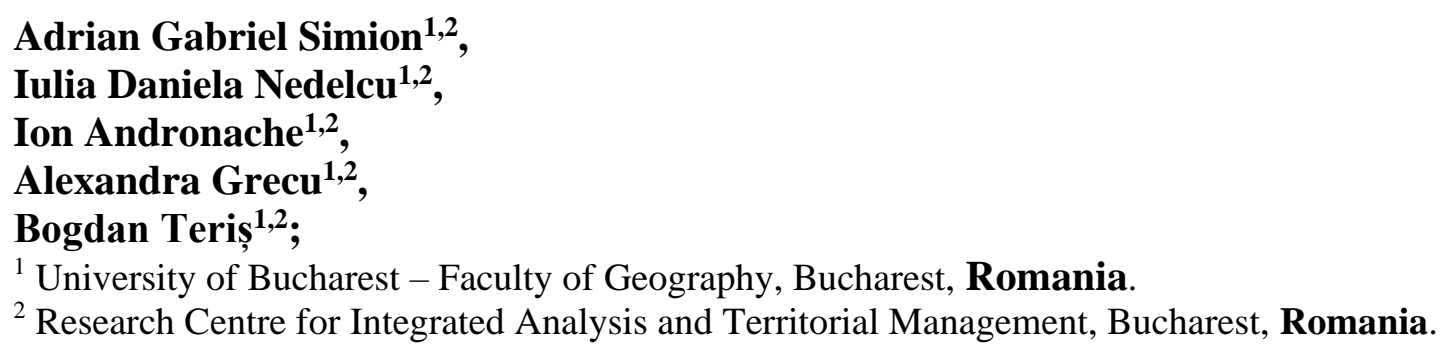

\begin{abstract}
The spectacular growth of deforested forest areas and the loss of large quantities of wood, in the short term, has led to significant changes in the local economy, with prospects of affecting the sustainable development. For this study we aimed to highlight the role of forestry cuts in the structural dynamics of the local economy. The research is based on a relevant statistical support, which includes the dynamics of the areas cleared between 2000-2018 and the evolution of the main economic indicators of the affected economies. In order to carry out this study we opted to use post-processed satellite images, to extract forest loss for the analyzed time interval, and national economic databases from which the specific codes for all economic activities in the locality were extracted. Following the application of the chosen methods we obtained a correlative image that indicates the impact of forestry practices on the economic profile of a locality. In some situations, the forest plays an essential role in the local economies, this being highlighted by our analysis.
\end{abstract}

Keywords: Forestry, forest dynamics, deforestation, forest exploitation

\section{INTRODUCTION}

The forest is regarded as an important part of the ecosystem but also of the territorial systems, being an important economic source, which is why it has been a very debated topic throughout history. The economic pressure exerted on this component is a problem that the present society faces, with effects both on the environment and on the level of the territorial units, causing serious imbalances [1], [2], [3]. Being a limited resource unevenly distributed on the Earth's surface, its understanding is being attempted by monitoring it, which requires complex approaches, methods and specific techniques to obtain the most relevant results [4]. As technology develops, the methods and techniques used provide more information. There are a number of programs launched in the contemporary period, which provide databases on the situation of forests, obtained by satellite image processing [5], [6].

From the specialized literature we find that the economic pressure exerted on the forestry component, both at global, regional but also local level, has negative effects with special importance on the environment, being one of the main factors underlying the changes that have occurred on the fauna and flora [7], on climate change, on $\mathrm{CO} 2$ concentration in the atmosphere [8], and on soil quality, when changing the land use category covered by 
forests in the past [9], [10]. All these consequences of deforestation plus many others, can be combated or at least mitigated by a method, namely by afforestation or reforestation of deforested surfaces [11]. All these changes occurring at the forest, temporary and spatial surfaces can be tracked using GIS and remote sensing techniques by analyzing and interpreting aerial and satellite images [12], [13].

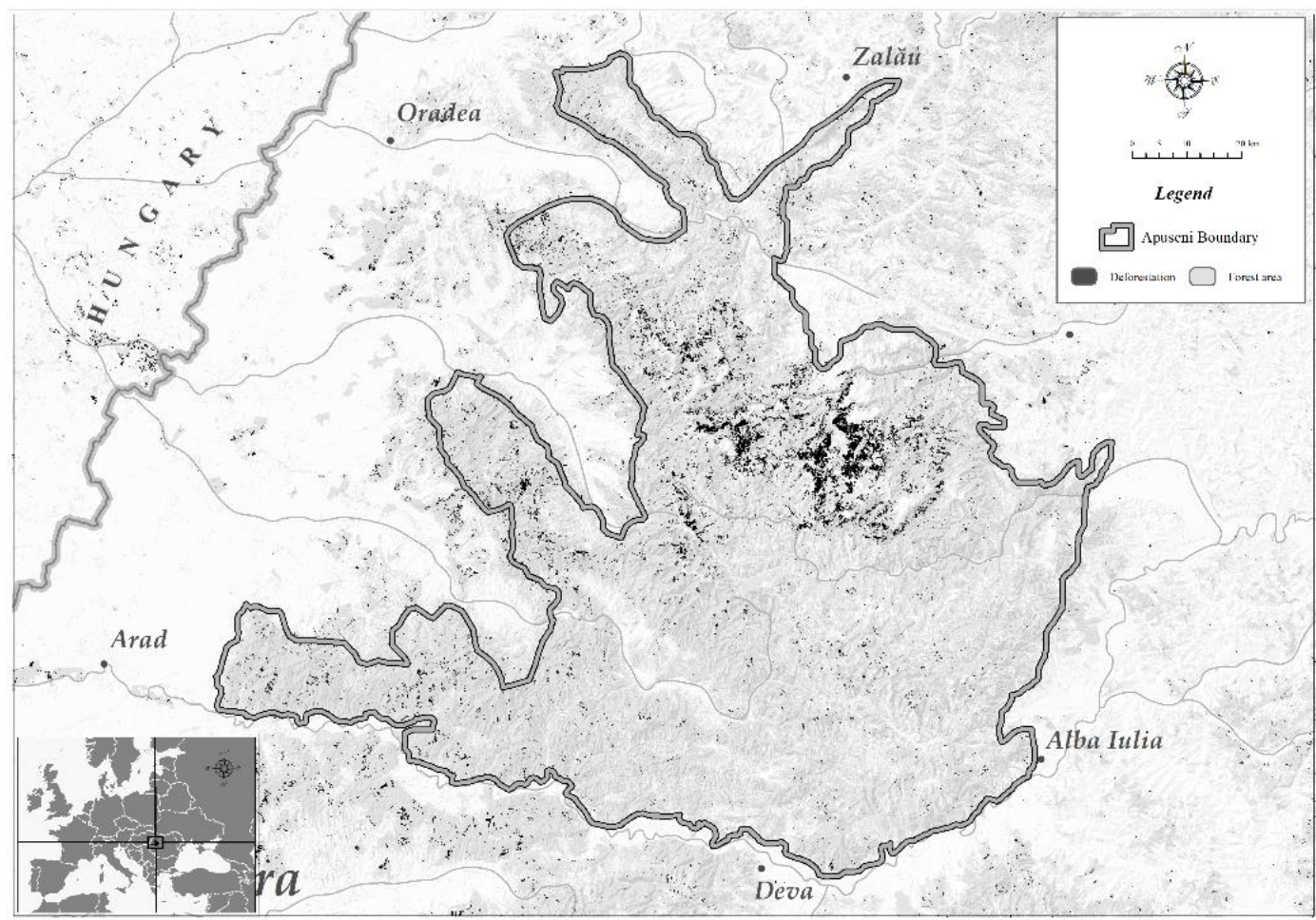

Figure 1. Study area

At the global level, the decrease of the forest areas is due to the change of the use category as a result of the development of the urban areas, hence the need for new agricultural land [14]. Although the forest area has decreased drastically in the last century, the overall deforestation rate has dropped by over $50 \%$ due to the implementation of specific public policies. This ecosystem comprises over $75 \%$ of the terrestrial biodiversity of particular importance to the rural population. The effects of deforestation, especially in tropical areas, lead to climate change by decreasing the amount of precipitation, respectively higher temperatures and drying [15], increasing $\mathrm{CO} 2$ emissions by up to $26 \%$ [16], and forming landslides specific to deforested areas. with a slope between 10 and 40 degrees [17]. At the global level, a program has been created to preserve the areas covered with forests, called UN-REDD applied in over 60 developing countries [18]. One obstacle to achieving the objectives proposed under this program is the corruption that allows the realization of illegal actions in terms of forest fund management [19], [20]. Romania remains one of the few countries in the temperate region of Europe where there are still virgin forests, with numerous protected areas and natural parks as part of the Natura 2000 program [21]. ]. Immediately after the fall of the communist regime, part of the forestry fund disappeared, leading to a drastic decline in the annual forestry fund [22]. The main causes of the decrease of the forest fund are the export of wood materials, but also their use as a source of heating of the houses, especially in the rural areas [23]. 
In this study we propose to show the role of the forest in the local economies, and the importance of using the right imagery dataset in order to obtain and to compare the official economic values.

\section{METHODS}

The chosen study area is made of the Apuseni Mountains, part of the Wester Carpathians from Romania. The Apuseni Mountains are part of the shortest mountain group from Romania, fact that made possible the development of most human settlements in the mountain areas from the country. Inside its border there are 171 settlements part of 6 counties and 3 development regions (Figure 1).

\section{Data processing}

The study is based on a detailed economic database that shows relevant data at Administrative Unite level, about the turnover, number of companies, number of employees and income value for each kind of activity structured by the National Economic Activities Classification (CAEN). The database was processed in order to be analyzed for the Apuseni Mountains and by certain activities. As an image database it was used an international forestry database, published by the Departament of Geographic Science, Maryland University. The database is called Gobal Forest Change (GFC) and is a Landsat database result that aims the forest loss evolution globally. The database is composed of three main datasets. The first one is named "treecover2000" and is the first image from the database, and it shows the forest cover from the year 2000. The second image is named "gain" and it shows the forest gain area between 2000 and 2012. The last one and the most important for this study was the dataset named "lossyear" which shows the evolution of the forest loss area between 2001-2018, year by year. The dataset contains classified pixels with values between $0-18,0$ being null and 1-18 being each year between 2001-2018. The main dataset is provided as a GeoTIFF image that was processed and from which was extracted a subset for the study area. The image was analyzed in ArcGIS and the resulted data table was used to be compared with the economic dataset evolution.

\section{RESULTS}

\section{Evolution of the share of the turnover of the forestry activities from the total turnover 2000-2018}

Analyzing the evolution of the turnover shows that the forestry activities presents a relatively constant percentage between 2000 and 2018. The ratio between this type of activities and total turnover of the settlements is somehow constant in the whole period. It can be seen a decrease near 2009 from $6.6 \%$ to $6.1 \%$ and an increase after his year to $8.7 \%$ (Figure 2). 


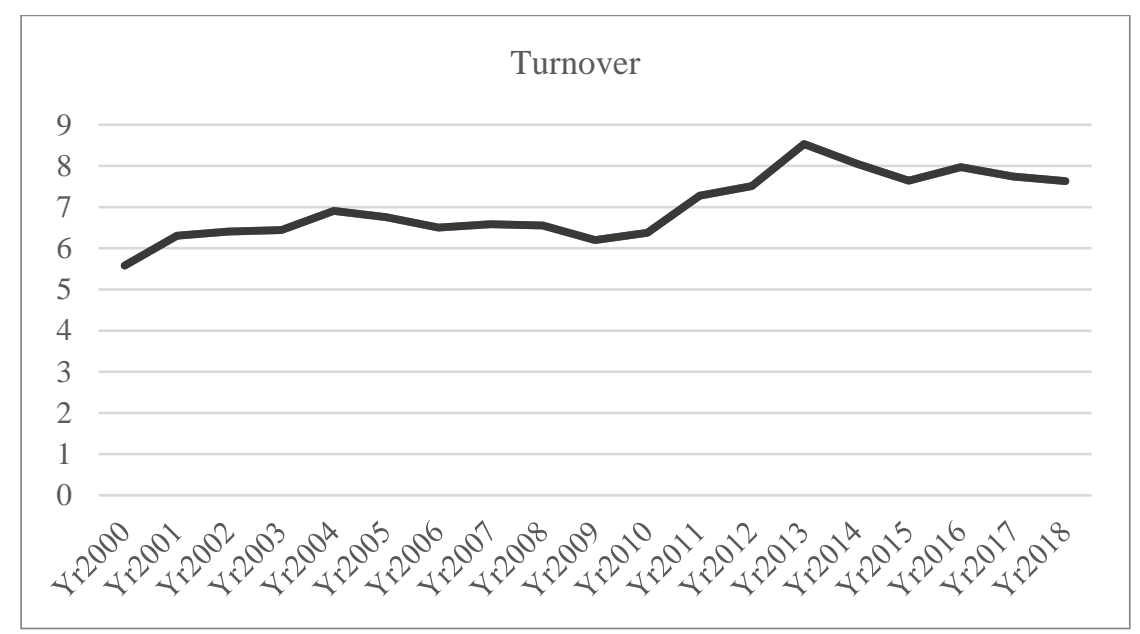

Figure 2. Share of the turnover of the forestry activities from the total turnover 20002018

\section{Evolution of the share of the number of Employees}

\section{of the forestry activities from the total turnover 2000-2018}

Regarding the ratio of the number of employees it shows a visible decrease between 20082009. That period of time is known by the Global Economic Crisis, that affected the most part of the economy. The number of employees decreased from 8019 (2007) to 6432 (2009-2010) from 8.8\% from total economy to 5\% (Figure 3).

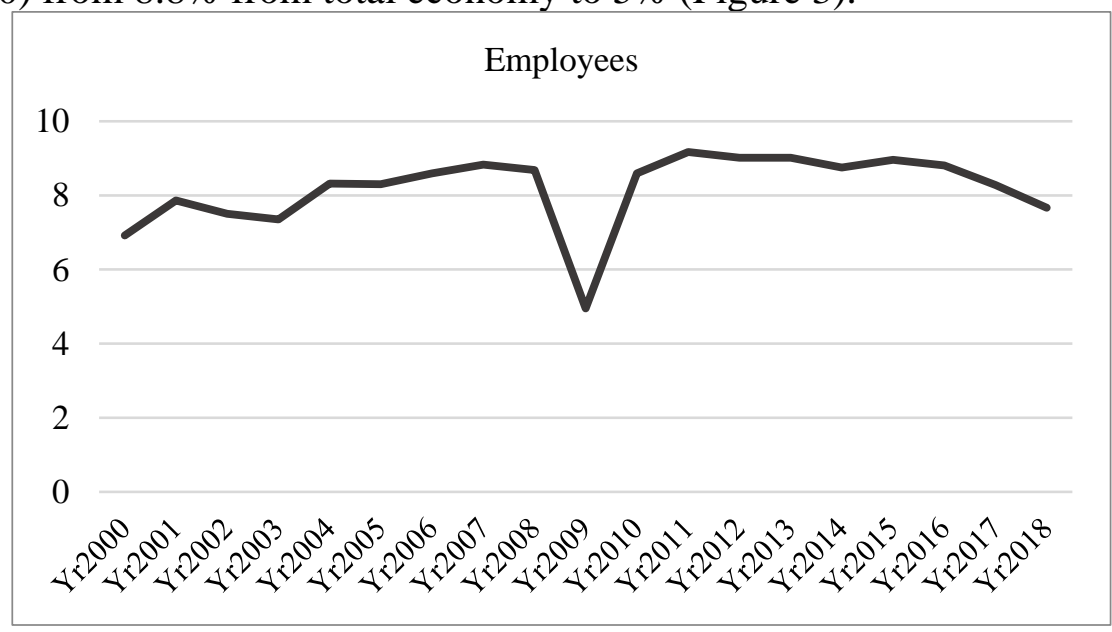

Figure 3. Share of the number of Employees of the forestry activities from the total turnover 2000-2018

\section{Evolution of the share of the number of companies}

\section{of the forestry activities from the total turnover 2000-2018}

The number of companies from this kind of business didn't felt any changes through the economic crisis. Even e can observe a decrease from $6.6 \%$ in 2001 to 5\% 2002, the number of companies actually increased from 412 to 534 between 2000-2002. After those years we don't see any relevant changes, but if we want to see the effects of the economic crisis, looking at the raw data we can see an important increase of companies between 2006-2007 ( 1000 companies) to 1300 companies in 2008 and after, until 2018 (Figure $4)$. 


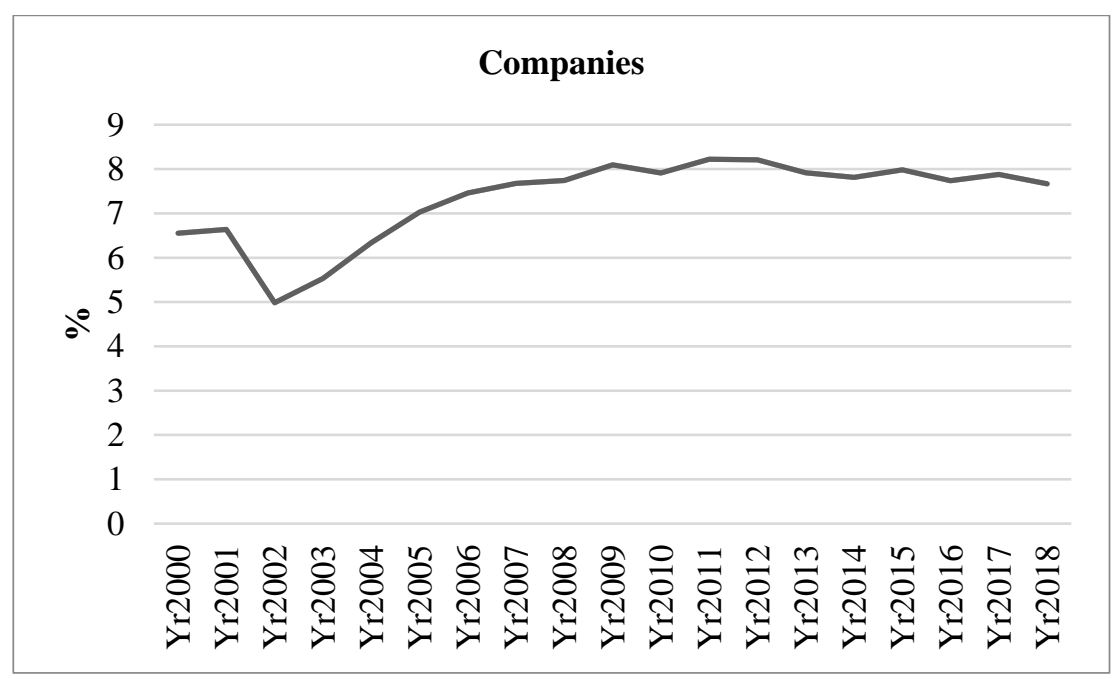

Figure 4. Share of the number of companies of the forestry activities from the total turnover 2000-2018

\section{Evolution of the forest loss area between 2001-2018}

The results of extracting the loss area from the satellite imagery showed an obvious increase in the deforested area between 2007-2009, from an average forest loss of $1500 \mathrm{ha} / \mathrm{year}$ to $7800 \mathrm{ha}$. This was the period represented by the Global Economic Crisis after which the exploitation area decreased and it increase again between 2010 and 2013 but about half of the first period (Figure 5).

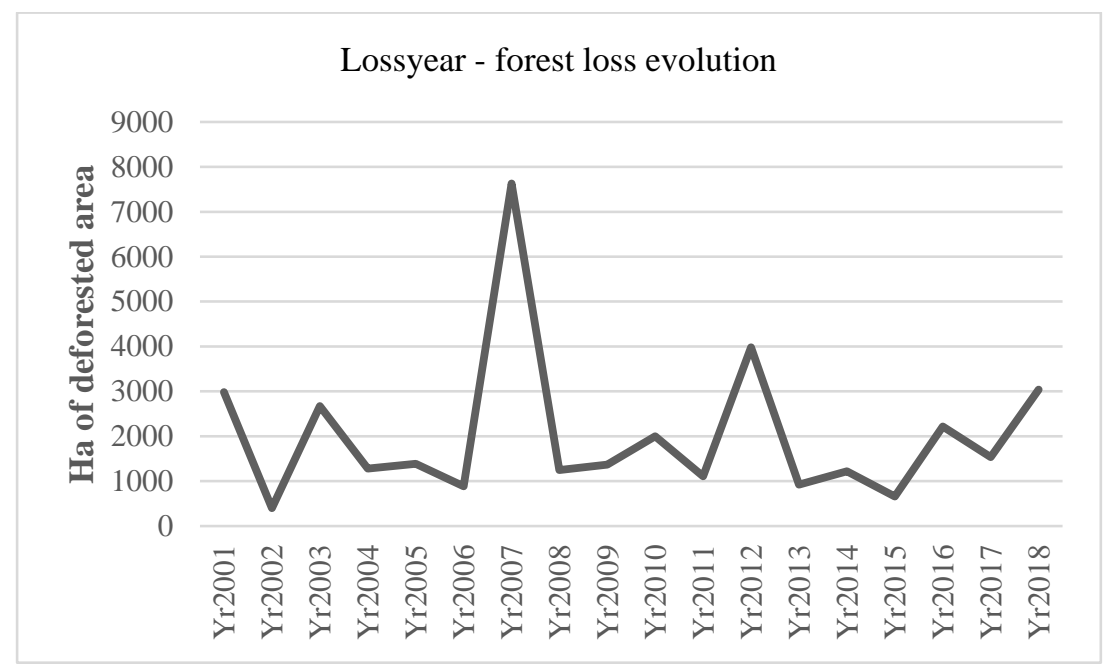

Figure 5. Forest loss evolution between 2001-2018

\section{CONCLUSIONS}

This study does not fully confirm its hypothesis because the forest exploitation does not affect the local economy very visible. Considering that, it exists an notable increase of forest loss area in 2008 with no significant changes in the economic indicators. In the employees case even it exists a decrease in the same time period, there are no significant increases. 
Therefore even the main objective was not achieved, this study shows the importance of the GIS analysis and satellite imagery usage in order to observe forestry indicators dynamics.

\section{REFERENCES}

[1] Moutinho, P. Preface, Deforestation around the world edited by Paulo Moutinho,2012;

[2] Pintilii, R. D., Andronache, I., Simion, A. G., Drăghici, C. C., Peptenatu, D., Ciobotaru, A. M., Dobrea, R. C., Papuc, R. M. Determining forest fund evolution by fractal analysis (SuceavaRomania), Urbanism Architecture Constructions, 2016, vol. 7, pp 31-42;

[3] Peptenatu, D., Merciu, C., Merciu, G., Drăghici ,C., Cercleux, L. Specific features of environment risk management in emerging territorial structures, Carpathian Journal of Earth and Environmental Sciences, 2012, vol. 7, pp 135-143;

[4] FAO (2015), Global Forest Resources Assessment Desk reference, Food and agriculture Organization of the United Nations (FAO);

[5] Achard, F., Beuchile, R., Mayaux, P., Stibig, J. H., Bodart, C., Brink, A., Cabroni, S., Desclee, B., Donnay, F., Eva, D. H., Lupi, A., Rasi, R., Seliger, R., Simonetti, D. Determination of tropical deforestation rates and related carbon losses from 1990 to 2010 Global Change Biology, 2014, vol 20, pp 2540-2554;

[6] Hansen, M. C., Potapov, P. V., Moore, R., Hancher, M., Turubanova, S. A., Tyukavina, A., Thau, D., Stehman, S. V., Goetz, S. J., Loveland, T. R., et al. High-Resolution Global Maps of 21st-Century Forest Cover Change. Scienc, 2013, 342, pp 850-853

[7] Zambrano-Monserrate, A. M., Carvajal-Lara, C., Urgiles-Sancez, R., Ruano, A. M. Deforestation as an indicator of environmental degradation: Analysis of five European Countries, Ecological Indicator, 2018, vol 90 pp 1-8;

[8] Anton, D. J. Diversity, globalization, and the ways of nature, IDRC, ISBN: 0-88936-724-8, Chapter 4. Forests under Attack, 1995, pp 39-63;

Boardman J., Poesen J. (2006) Soil Erosion in Europe, John Wiley \& Sons, Ltd, Section 1, 2006;

[9] Boardman J., Poesen J. (2006) Soil Erosion in Europe, John Wiley \& Sons, Ltd, Section 1, 2006;

[10] Foley, J. A., DeFries, R., Asner, G. P., Barford, C., Bonan, G., Carpenter, S. R., Chapin, F. S., Coe, M.T., Daily, G. C., Gibbs, H. K., Helkowski, J. H., Holloway, T., Howard, E. A., Kucharik, C. J., Monfreda, C., Patz, J. A., Prentice, I. C., Ramankutty, N., Snyder, P. K. Global Consequences of Land Use, Science, 2005, pp 570-574;

[11] IPCC Climate Change 2014: Synthesis Report. Contribution of Working Groups I, II and III to the Fifth Assessment Report of the Intergovernmental Panel on Climate Change [Core Writing Team, R.K. Pachauri and L.A. Meyer (eds.)]. IPCC, Geneva, Switzerland, 2014;

[12] Hansen, M. C., Potapov, P. V., Moore, R., Hancher, M., Turubanova, S. A., Tyukavina, A., Thau, D., Stehman, S. V., Goetz, S. J., Loveland, T. R., et al. High-Resolution Global Maps of 21st-Century Forest Cover Change. Scienc, 2013, 342, pp 850-853.

[13] Kim D.-H., Sexton O.J., Noojipady P., Huang C., Anand A., Channan M.F., Townshend R.J. 2014 Global, Landsat-based forest-cover change from 1990 to 2000, Remote Sensing of Environment;

[14] FAO. State of the World ís forests. 2014, Forest and Agriculture: Land -Use challenge and opportunities. Rome, Italy. http://www.fao.org/3/a-i5588e.pdf;

[15] Lawrence D., Vandecar K., 2015. Effects of tropical deforestation on climate and agriculture. Nature Climate Change. 5:27-36. http://dx.doi.org/10.1038/nclimate2430 
[16] DeFries S.D., Houghton A.R., Hansemn C.M., Field B.C., Skole D., Townshend J., 2002. Carbon emissions from tropical deforestation and regrowth based on satellite observations for the 1980s and 1990s, PNAS;99(22):14256-14261. https://doi.org/10.1073/pnas.182560099

[17] Heshmati M., Arifin A., Shamsuhuddin J., Majid N.M., Ghaituri M., 2011. Factors affecting landslides occurrence in agro-ecological zones in the Merek catchment, Iran. Journal of Arid Environments;75(11):1072-1082. doi: 10.1016/j.jaridenv.2011.06.011

[18] UN-REDD Programme. http://www.un-redd.org/; 2018

[19] Sheng J., Han H., Miao Z., 2016. Effects of corruption on performance: Evidence from the UN-REDD Programme. Land Use Policy, 59:344-350

[20] Sundström A., 2016. Understanding illegality and corruption in forest governance. Journal of Environmental Management, 181(1): 779-790

[21] Romanian Environment Ministry - www.mmediu.ro

[22] Pintilii R.D., Andronache I., Simion A.G., Draghici C.C., Peptenatu D., Ciobotaru A.M., Dobrea R.C., Papuc R.M., 2016. Determining forest fund evolution by fractal analysis (SuceavaRomania). Urbanism Arhitecture Constructions, 7(1):31-42.

[23] Pintilii R.D., Papuc R.M., Draghici C.C., Simion A.G., Ciobotaru A.M., 2015. The impact of deforestation on the structural dynamics of economic profile in the most affected territorial systems in Romania. In Proceeding of 15th International Multidisciplinary Scientific Geoconference (SGEM), Albena, Bulgaria, 3(2), p. 567-573. 